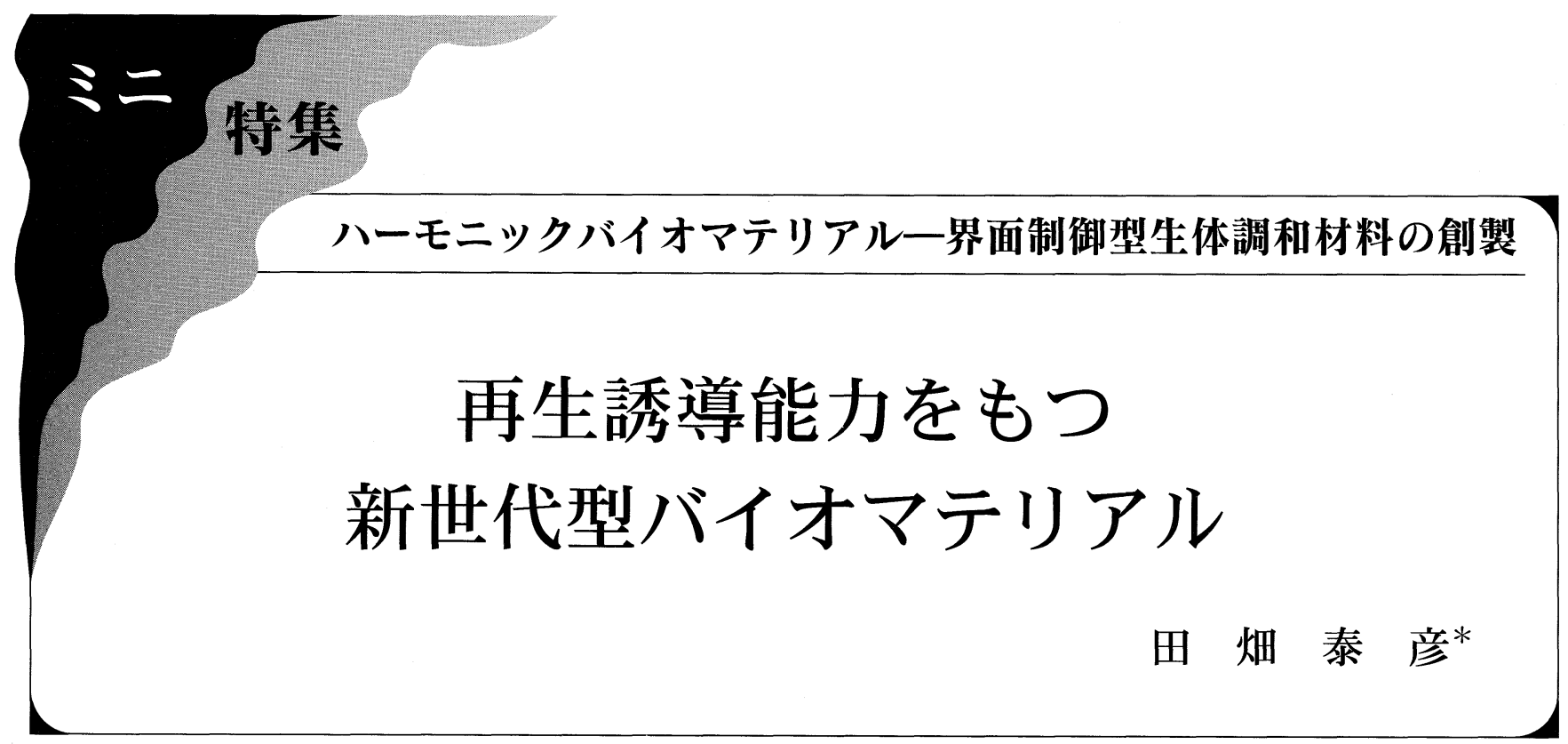

\section{1. バイオマテリアル概念の変遷}

バイオマテリアル(生体材料) とは，生体内で用いる，ある いは細胞, タンパク質, 核酸, 細菌などの生物成分と触れて 用いるマテリアル(材料)である. その中には, 高分子, 金属, セラミックス，抽よ゙それらの複合体など，全ての材料が含 まれる、これまで, バイオマテリアルといえば, 外科, 内科 治療に必要々なる医療用材料, 人工蔵器が研究の中心であ り，血液が凝固しない，あるいは血栓を作らない性質(抗血 栓性), 細胞や組織とのなじむ性質(生体適合性), 溶血(赤血 球が破裂すること)や炎症を起こさないような性質をもつ材 料の研究開発に主眼が置かれてきた。これまでに，細胞と材 料との相互作用が，分子レベルで検討され，多くの基礎的知 見が蓄積され，その知見を基に材料が様々に医療現場で用い られている.しかし, 現在においても, 完璧な抗血栓, 生体 適合性バイオマテリアルは得られていない。このように，こ れまでのバイオマテリアル研究開発の方向性は, 生体に対し て積極的に働きかけるのではなく, 細胞や, 組織に悪い刺激 を与えず，生体とうまく融合させるという材料設計であった.

人工蔵器以外のバイオマテリアルの応用にドラッグデリバ リーシステム (DDS)がある.治療薬とバイオマテリアルと を組み合わせ, 薬の副作用を軽減, 主作用を増強する技術, 方法論である.この場合も, 人工臓器と同じく, 生体のもつ 炎症，異物防御システムに刺激を与えず，うまく，それを回 避するという方向で研究が進められてきた。しかしながら， 近年，バイオマテリアルの研究は大きく変化してきている. これまでのような生体側から認識されず，排除されないよう な生体になじみ, 融和する性質を求めるのではなく, 逆に, 生体に積極的に働きかける性質をもつ材料の研究開発が始ま
っている. その代表例が, 生体組織の再生誘導治療(一般に は, 再生医療と呼ばれている)である. バイオマテリアルを 活用することで, 生体のもつ再生誘導能力を高め, 生体組織 を再生修復する(1)-(5). DDS も, 治療薬の久がその研究対象 ではなく，生物作用をもつあらゆる物質を「薬＝Drug」と 考え, より広い技術領域を包括するバイオマテリアル研究分 野として考えられている(6)(7).

\section{2. 再生誘導治療におけるバイオマテリアルの重要性}

イモリのしっぽが再生する現象をヒトで誘導し, 治療に役 立てようとする試みが, 再生誘導治療である. その基本アイ デアは, 細胞の増殖, 分化能力を最大限に活用することによ り, 生体組織を再生誘導させることである. 体に本来, 備わ っている自己の自然治癒力を高め, 病気を治すアプローチ は, 体にやさしい理想的な治療法となる. もちろん, この再 生誘導治療にも長所と短所があるが, 生体融和型のバイオマ テリアルを利用したこれをでの再建外科や臓器移植の 2 大 先端外科治療の欠点を補い, 治療の選択肢を増すとともに, 治療の適用拡大抢よび新しい治療技術も可能となることか ら，近年，第 3 の治療法として期待されている. 加えて， 治療薬を投与する内科的治療手段により, 組織の再生誘導能 力を高め, 肝硬変, 肺線維症, 慢性腎炎などの難治性慢性線 維性疾患を治療したり ${ }^{(8)}$, 血管壁にできた瘤(動脈瘤)を生体 組織によって完全に閉鎖してしまうという画期的な血管内力 テーテル治療(これまでは血栓によって閉鎖され，血栓の再 溶解による瘤の再形成が問題であった.)などの試みも始めら れている(9). 今後は, 内科治療に抢いても再生誘導治療は重 要な役割を演じていくと考えられる(3)(4).

この再生誘導治療が現実味を帯びてきた背景に，2つの研

* 京都大学再生医科学研究所教授; 生体組織工学研究部門生体材料学分野 ( $\mathbf{T} 606-8507$ 京都市左京区聖護院川原町53)

Biomaterials of New Generation to Induce Tissue Regeneration; Yasuhiko Tabata (Department of Biomaterials, Field of Tissue Engineering, Institute for Frontier Medical Sciences, Kyoto University, Kyoto)

Keywords: biomaterials, tissue engineering, regenerative medical therapy, drug delivery system (DDS), scaffold, biological signaling molecules 2007年 2 月 5 日受理 
究分野の進歩があることを忘れてはならない.1つ目の研究 分野は，再生現象に関わる基礎生物医学(再生医学々呼ばれ る)である. 現在, 増殖, 分化能力の高い細胞の存在が明ら かになってきてはいるが，ただ単に，細胞を体内に注入する だけでは，生体組織の再生誘導が期待できない場合も多い。 これは, 細胞の生存と機能発現に, 細胞とその局所周辺環境 との相互作用が不可欠であることを考えれば当然である。そ こで，生体組織の再生を誘導することを目的とした細胞の増 殖, 分化を促す環境(場)を作り与える医工学技術，方法論が 必要不可欠である.これが，2つ目の必要分野としての生体 組織工学であり，バイオマテリアルがその基礎となってい る. 人工的に作製できるバイオマテリアルや利用可能な生体 シグナル因子(ペプチド, タンパク質, 遺伝子など)を利用, 体内に存在している創を治す㗢きをもつ細胞を再生部位に呼 び込久, 生体本来のもつ創傷治瘉能を促し, 生体組織の再生 を誘導する，今や，再生医療を実現させるためにバイオマテ リアルは必要不可欠な存在となっている. 再生医学が進歩 し, 再生のメカニズムが解明されることが大切であることは いうまでもないが，その進歩が直接，患者の治療(つまり, 再生医療)にはつながらないことも多い，再生医学と再生医 療とは大きく異なる。これまでのバイオマテリアル研究開発 の知見とその臨床応用の実績を基に, 再生誘導現象の生物医 学研究との組み合わせによって, バイオマテリアルが再生医 療を実現させていくことは疑いない.

\section{3. 再生誘導治療の中でのバイオマテリアルの役割}

再生誘導治療の目的は, 欠損した生体組織の再生誘導と荒 廃した臓器の機能代替による病気の治療である. 体のしくみ が完全には解明されていないことに加えて, 生体組織の再生 修復についての限られた生物医学の知識と細胞培養技術のみ では, 生体外で再生誘導の場を設定することはきわめて困難
である.これに対して, 生体内では, 再生誘導に必要な物質 が供給されると考えられ, 自動的な再生誘導の場の設定も期 待できる.このことから, 現時点では, 生体内アプローチに よる生体組織の再生誘導が現実的である(1)-(4). その基本的 な戦略は, 生体組織の構成 3 要素である細胞, 細胞外マト リクス(生体由来のタンパク質, 多糖などからなっている), および生体シグナル因子(ペプチド, タンパク質, 遺伝子な ど)を組み合わせて, 生体組織や臓器の再生を誘導すること である，組織の構成要素およびそれらの相互作用に関する基 礎生物医学研究を推進し, さらにその研究成果の臨床応用へ の展開に対して，バイオマテリアルの利用はきわめて有効で ある(図 1)。

再生医療では, 臨床利用できる質のそろった多量の細胞を 準備しなければならない, 必要な細胞を単離, 増殖, 分化さ せるための培養技術, 万法論の研究開発が不可欠となる. 例 えば，生体内環境を模做した 3 次元の人工細胞外マトリク ス(足場材料と呼ばれている)(3)(10)(11)ができれば, 幹細胞の 分離, 増殖, 分化効率を高めることができるであろう ${ }^{(12)}$ (図 1(A)). さらに, 細胞培養法, 装置(バイオリアクタ)の改 良, 遺伝子導入による細胞の生物機能を増強させるための遺 伝子改変技術の研究開発も大切である ${ }^{(3)}(7)$. 細胞とともに, 細胞外マトリクス屯でもなくなっているような時, 細胞を欠 損部に加えるだけでは再生誘導は期待できない, 細胞を立体 的に配置させ, その接着, 増殖, 分化促進のための適当な人 工足場の利用が不可欠である(図 $1(\mathrm{~B}))^{(10)}$. 足場の 3 次元成 形技術, その生体吸収性と内部構造制御技術, および生体シ グナル因子との組み合わせ技術などに関するバイオマテリア 儿研究開発がその key となる。不必要な細胞や組織の侵入 から生体組織の再生誘導のスペースを確保する技術も必要と なる(図 $1(\mathrm{C})$ ).

再生誘導にかかわる細胞増殖因子および遺伝子などの働き が解明され, 利用可能になってきているが, 生体内寿命の短

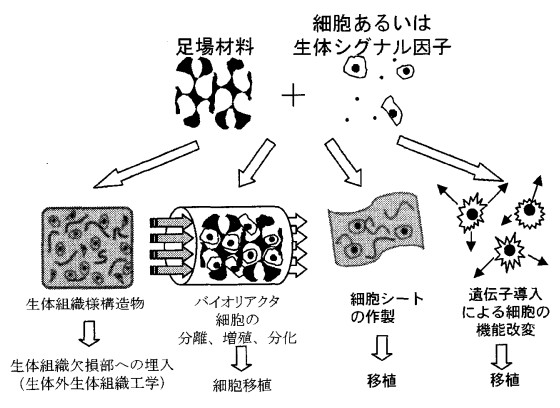

(A) 細胞の分離、増殖、分化のための バイオマテリアル足場と細胞培養技術、方法論

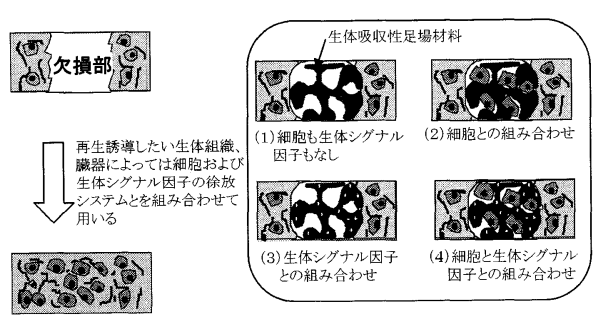

（B）生体組織の生体内再生誘導のためのバイオマテリ アル足場技術、方法論

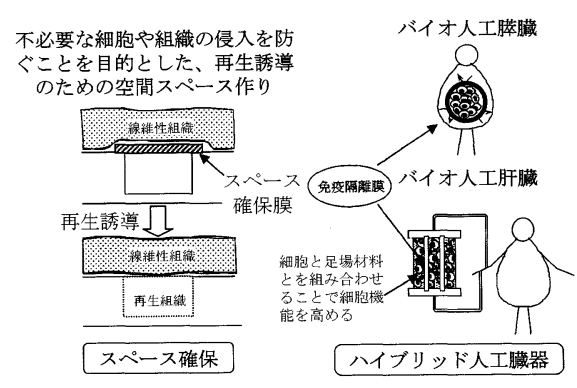

（C）生体内での生体組織の再生誘導スペースの確保 のためのバイオマテリアル技術、方法論

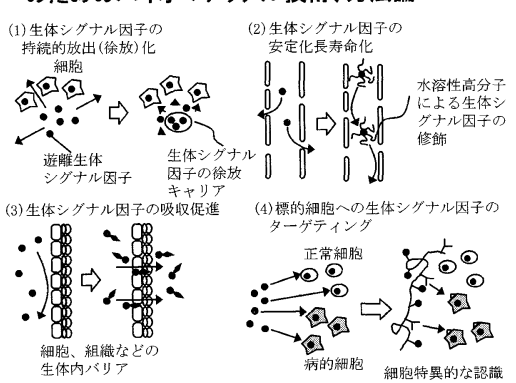

（D）生体シグナル因子の生物活性発現のための DDS用バイオマテリアル技術、方法論

図 1 バイオマテリアルを利用した生体組織の再生誘導治療のための基盤技術と方法論. 
く不安定な生体シグナル因子を，単に水に溶かして投与する たけでは，期待する組織の再生促進効果は得られない。そこ で，再生の場に㧤い生体シグナル因子の濃度を必要な期間 にわたって有効值に保つためのDDS技術が必要である (図 $1(\mathrm{D}))^{(6)}$. 例えば, 細胞増殖因子を再生の場で持続的に 放出(徐放)させることができれば，細胞の増殖分化が高ま り，自己組織の再生が促される。生体吸収性のバイオマテリ アルはこの徐放キャリアの役割を果たす(3)(6)(12)(13). 徐放化 システムは単独あるいは細胞とともに足場材料とを組み合わ せて生体組織の再生誘導に用いられる(図 1(B)) (1)-(4).

\section{4. バイオマテリアルを利用した再生誘導治療の実際}

欠損部位周辺組織の再生能力が高い場合には，欠損部へ生 体吸収性の足場材料あるいはスペース確保膜バイオマテリア 儿を与えるだけで組織の再生誘導は可能となる(1)。しかし， 欠損部周辺組織の再生能力が低いあるいは望めない場合に は, バイオマテリアルのみでは, 生体組織の再生誘導は期待 できない，そこで，細胞や生体シグナル因子の利用が必要と なる(図 1(B)) (2)-(4)(6)。前述のように，バイオマテリアルを 活用して，効率よく分離，培養した細胞を移植することで, 生体組織の再生誘導が試みらている(14)。生体シグナル因 子の利用には DDS 技術が不可欠である。例えば，生体吸收 性バイオマテリアルからなるハイドロゲルを利用することで 生物活性をもつ細胞増殖因子および遺伝子などの徐放化が可 能となり, すでに, この技術によって血管, 骨, 軟骨, 脂肪 などの生体組織の再生誘導が実現している(1)-(4) (図 2). 塩 基性線維芽細胞増殖因子 (bFGF) の徐放化技術を用いた虚血 性疾患に対する血管新生誘導治療, 胸骨と胸骨周辺軟組織の 再生治癒促進治療については, ヒトへの臨床試験が始まり, よい成績が得られている(15). いかに優れた能力をもつ細胞 でも, 酸素および栄養の供給がなければ, 生体内ではその生 存も生物機能の発現も期待できない，ハイドロゲルを利用し た徐放化 bFGF による血管誘導技術は，膵ランゲルハンス
島, 肝細胞, 心筋細胞, あるいは腎尿細管上皮細胞の生体内 での機能維持ならびに細胞移植治療効果を有意に向上させる ことがわかっている(2)(3).ささらに,この時，バイオマテリア 儿足場を組み合わせることで, より効率のよい生体組織の再 生誘導が認められている.

細胞増殖因子タンパク質ではなく，遺伝子を利用した生体 組織の再生誘導も試みられている(3)(4)(6)。例えば，プラスミ ド DNAの徐放化が遺伝子の発現レベルを高め, 発現期間を 延長した(13)。 また，細胞内でのプラスミドDNAの徐放 化 ${ }^{(16)}$, あるいはリバーストランスフェクション法(7)(17)によ る遺伝子発現レベルの増強も期待できる.

これまで述べてきたように, 生体内の欠損部に外科的に再 生誘導の場を作る「外科的再生医療」とは異なり, 線維化組 織を消化分解することで, 臓器内に再生誘導の場を確保し, 周辺の正常組織の再生誘導能力を介して, 難治性慢性線維性 疾患の治療を行う「内科的再生医療」の試及も始末ってい る ${ }^{(3)}{ }^{(4)}$ (図 3). 従来型の「外科的再生」と「内科的再生」の いずれも, 生体の潜在的な再生誘導能力を引き出し, それを

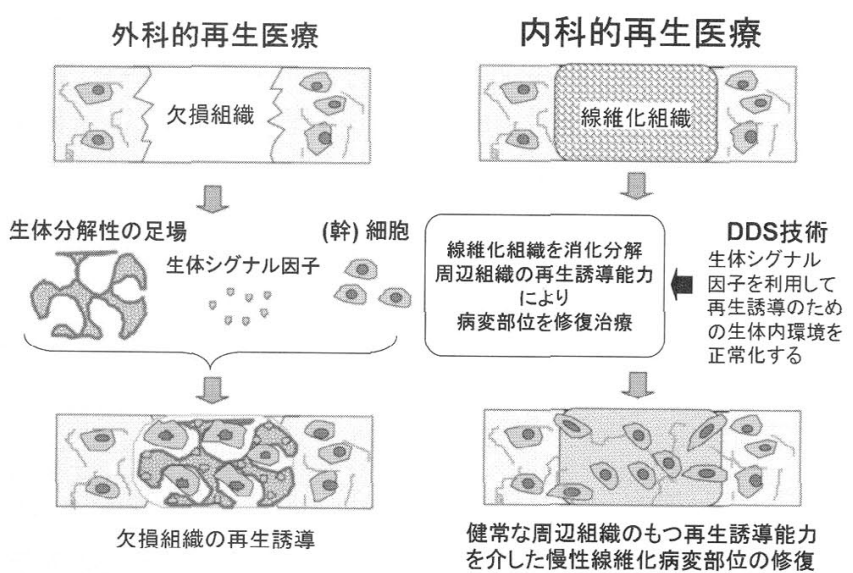

図 3 細胞, 足場, 生体シグナル因子の組み合わせに よる外科的再生医療とDDS 化生体シグナル因子 を利用した難治性慢性繊維化疾患の再生誘導治 療 (内科的再生医療)。

1)ゼラチンハイドロゲル(徐放のための担体)の分解にともなう細胞增殖因子の徐放化システム

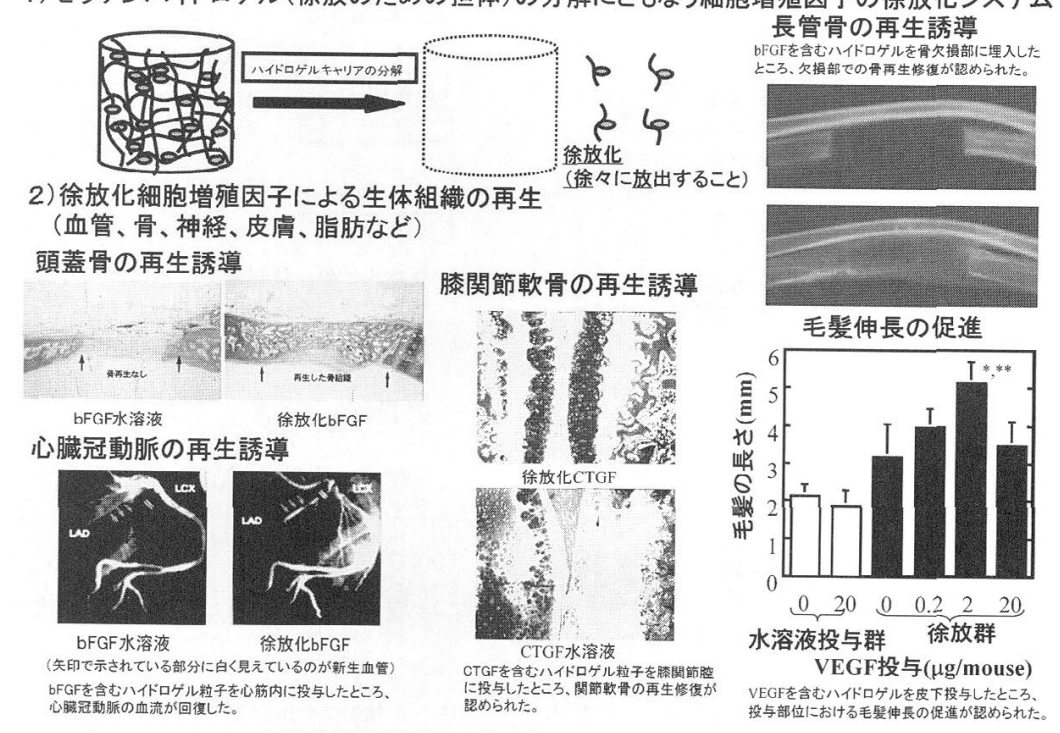

図 2 生体吸収性高分子ハイドロゲルを用いた細胞増殖因子の徐放化による様々な生体組織の再生誘導例(VEGF(血 管内皮細胞増殖因子), CTGF(結合組織増殖因子)). 


\begin{tabular}{|c|c|c|}
\hline 基礎生物医学 & $\begin{array}{l}\text { 細胞学 } \\
\text { 分子生物学 } \\
\text { 発生学 } \\
\text { 免疫学 } \\
\text { 生化学 } \\
\text { 実験動物学 }\end{array}$ & $\begin{array}{l}\text { 物質の細胞内への導入, 物質の細胞内動態の制御, 幹細胞工学 } \\
\text { 遺云子己改変, 遺伝子発現制御, 遺伝子解析 } \\
\text { 発生プロセスの解明と制御 } \\
\text { 免疫エフェクター細胞の機能とサイトカイン作用の解明と制御 } \\
\text { タンパク質, 遺伝子の安定化 } \\
\text { 病態モデル動物作製, 医療をめさした基璴研究 }\end{array}$ \\
\hline 医療 & $\begin{array}{l}\text { 治療 } \\
\text { 予防 } \\
\text { 診断 }\end{array}$ & 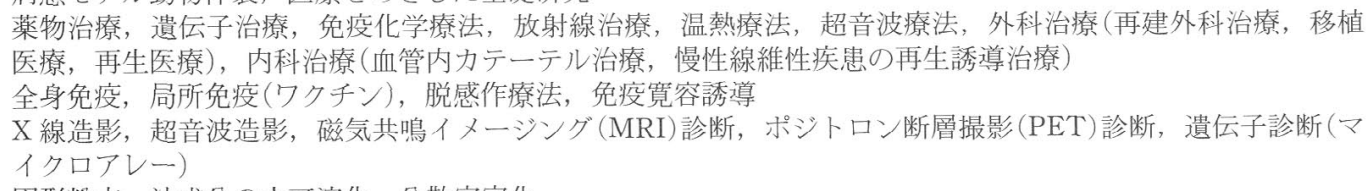 \\
\hline ヘルスケア & 化粧品 & 固形粉末, 油成分の水可溶化, 分散安定化 \\
\hline
\end{tabular}

利用して病気の治療のきっかけを与えるという点で共通して いる。細胞増殖因子，プラスミド DNA，扔よび small interference RNA（siRNA)のDDS化により, 線維化疾患の悪化 抑制上その発症抑制も可能になってきている(4)(18)-(20).

\section{DDS 概念の広がりとバイオマテリアルへの大き な期待}

バイオマテリアルの新しい方向性として, 生体組織の再生 誘導治療について紹介した。本稿では, 紙面の都合と小生の 勉強不足とからその具体例について全てを紹介することはで きなかったが，読者の皆様には，生体組織の再生誘導のため の場の構築には，足場，スペース確保，DDSなどの目的 に，生体吸収性のバイオマテリアルが重要でしかも不可欠な 存在であることがわかっていただけたものと信じている. 例 えば，再生誘導を促す生体シグナル因子を組久込久，細胞の 増殖，分化を促す性質をもつ足場がデザインできれば，これ までの融合型ではなく，積極的な再生誘導能力をもつバイオ マテリアルが実現できる。

DDS は薬物治療の効率を向上させることを目標として発 展してきたため, drug =治療楽＝薬物治療というこれまで の固定概念にとらわれていることが多い。しかしながら， DDSの目的，技術，方法論は薬物治療だけにとどまるもの であろうか. DDS とは, 生物活性をもつ物質の動きをコン トロールすることによって，その作用部位に望ましい濃度一 時間パターンのもとに選択的に送り达み, 結果として, 最高 の生物効果を得ることを目的とした，物質の送達に関する一 般概念である. 体外, 体内に関係なく, 不安定かつ作用部位 の特異性もない $\operatorname{drug}($ (物質)の動きをコントロールし, 生物 医学効果を発揮させるための材料・技術・方法論が DDS で あると考えれば, DDS が生物医学研究々医療の基盤技術で あることがわかるであろう. 再生誘導治療に扔いても, 生体 内で不安定な生体シグナル因子を利用する限り，DDS 技 術, 方法論は不可欠である. 表 1 にDDS 技術·方法論の導 入が必要と考えられる研究分野を示す。いずれの分野に括い ても, DDS 概念の導入による研究開発の成功には, バイオ マテリアルの寄与がきわめて大きい(5)(6).今後, バイオマテ リアル研究は, これまで以上に, 医学, 歯学, 薬学, 生物 学, 細胞学, 分子生物学などの基礎研究分野, 加えて, 医療 やへルスケアなどの応用領域と融合して発展していくであろ う.これは, これらの分野, 領域に㧍けるバイオマテリアル

の必要性, 重要性が認められてきたためである。今一度, 広 範囲に応用可能なバイオマテリアルの位置付けを再認識して いただきたい。少しでも多くの人たちのバイオマテリアルに 対する関心が高まり，今後，バイオマテリアル学が大きく開 花することを願って止まない。

\section{文献}

（1）田畑泰彦編：ここまで進んだ再生医療の実際。羊土社, (2003).

(2) Y. Tabata: Tissue Eng. 9 Suppl, 1(2003), S5-15.

(3) 田畑泰彦編：遺伝子医学 MOOK. メディカルドゥ：大阪, (2004).

(4) Y. Tabata: Drug Discovery Today., 10(23-24), (2005), 16391646.

（５）田畑泰彦編：再生医療のためのバイオマテリアル，再生医療 の基礎シリーズ一生医学々工学の接点一5. コロナ社：東京， (2006).

（6）田畑泰彦編：ドラッグデリバリーシステムDDS 技術の新たな 展開とその活用法. 遺伝子医学別冊。メディカルドゥ, (2003).

（7）原島秀吉, 田畑泰颜編：ウイルスを用いない遗伝子導入法の 材料, 技術, 方法論の新たな展開. 遺伝子医学 MOOK. メデ ィカルドゥ：大阪，（2006）.

(8) 山本雅哉: Drug Delivery System, 20(2005), 110-117.

(9) 宮本 享, 川上理, 波多野武人, 山田圭介, 田畑泰彦: Drug Delivery System, 20(2005), 118-127.

(10) 田畑泰彦: THE BONE, 17(2003), 29-34.

(11) Y. Hiraoka, Y. Kimura, H. Ueda and Y. Tabata: Tissue Eng., 9(2003), 1101-1112.

（12）田畑泰彦：臨床眼科, 59 (2005), 229.

(13) M. Yamamoto and Y. Tabata: Adv Drug Deliv Rev., 58 (2006), $535-554$.

(14）浅原孝之：先端医療の最前線. Vol. 1. 2006, 東京：羊土社.

(15) 丸井茪, 田烟泰彦, 福島雅典, 北徹, 中尾一和, 木村 㲏, 伊藤 裕, 松井茂之, 長谷川浩二, 堀内久徳, 原田 昌樹, 山本雅哉, 小帛伸介, 仁科健, 池田 義, 米田正 始 : Cardiovascular Med-Surg., 8(2006), 83-87.

（16）永谷憲歳：Drug Delivery System, 20 (2005), 105-109.

(17) A. Okazaki, J. Jo and Y. Tabata: Tissue Eng., 13 (2007), 245251.

(18) 山本雅哉, 田畑泰彦: 慢性疾患治療, 田畑泰彦(編)，メディ カルドゥ：大阪，(2004), 266-272.

(19) T. Kushibiki, N. Nagata-Nakajima, M. Sugai, A. Shimizu and Y. Tabata: J. Control Release, 105 (2005), 318-331.

(20) 山本雅哉: DDS, 20 (2005), 110-117.

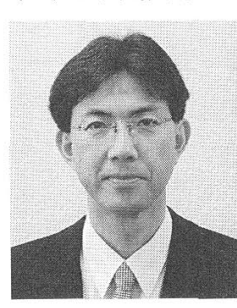

田畑泰彦

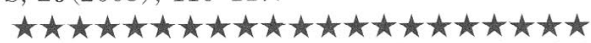
1983年 京都大学大学院工学研究科高分子化学専攻 修了

1988年 京都大学医用高分子センター助手 1998年 京都大学生体医療工学研究センター助教授 2000年 3 月-現職.

2001年 大阪大学大学院医学系研究科教授

専門分野：バイオマテリアル，生体組織工学，ドラッ グデリバリーシステム(DDS), 幹細胞工学 サイボーグの夢を求めて，生体吸収性高分子を用いた 先端医療用材料の研究老続けている。生命科学のわか る材料科学研究者を苔て、世の中に還元でさるサイエ ンス存目指したい。京都大学から工学，医学，薬学の 3 つ博土号を取得. 工, 医歯, 薬学系 13 大学の非常 勤講師. 